\title{
TURCJA W POLITYCE BRYTYJSKIEJ WOBEC SYRII I LIBANU W LATACH 1940-1941
}

\author{
Krzysztof Zdulski* \\ TURKEY IN BRITISH POLICY TOWARDS SYRIA AND LEBANON \\ IN 1940-1941
}

\begin{abstract}
After collapse of metropolitan France in June 1940, the French in the Syria and Lebanon swore allegiance to the Vichy Government. This situation was hard to accept by the British. According to the Chiefs of Staff Committee, the occupation of these territories by enemy forces could have had most serious strategic consequences since it would cut of land communications with Turkey and would immediately threaten the whole of British interests in the Middle East. Due to that threat, London was forced to rethink its policy towards French Levant. One of the discussed measures was a proposition to involve Turkey in solving this problem. Turkey was bound with Britain with reciprocal security pact since October 1939. Moreover, the situation in Syria and Lebanon was also a threat for Turkish security. It was thought that these arguments would act in favor of Turkish involvement. Although in London everyone counted on active attitude of Turkey, there was no agreement as to its nature. While Churchill, Eden and the Chiefs of Staff were willing to agree on Turkish occupation of Syria and Lebanon, the Foreign Office was definitely against this solution. The first option eventually won. The first serious talks about Turkish involvement in Levant question took place in Ankara in January 1941, during the Anglo-Turkish military conversations. It was agreed then that if Turkey had entered the war, Turkish and British armies would have occupied Syria and Lebanon. The deteriorating military situation on the Eastern Mediterranean forced the United Kingdom to intervene in the French Levant in June 1941. The British government
\end{abstract}

* Uniwersytet Łódzki, Wydział Studiów Międzynarodowych i Politologicznych. 
encouraged Turks to take part in that operation ("Exporter"). However, Turkish government rejected that offer. Turkey was still out of war and did not want to worsen her relations with the Third Reich.

\section{- KEYWORDS}

the United Kingdom, Turkey, Second World War, the Levant

Dla Wielkiej Brytanii jednym z wielu negatywnych skutków kapitulacji Francji w czerwcu 1940 roku była perspektywa dostania się francuskich posiadłości zamorskich w ręce obozu Osi. W przypadku Syrii i Libanu, którego władze uznały zwierzchność rządu Vichy, niosłoby to ze sobą poważne konsekwencje w wymiarze strategicznym. W raporcie Komitetu Szefów Sztabów (CSC) pisano, że oznaczałoby to przecięcie komunikacji lądowej z Turcją oraz bezpośrednio zagroziłoby pozycji brytyjskiej na Bliskim Wschodzie ${ }^{1}$.W domyśle chodziło tutaj o ewentualną ofensywę przez Palestynę na Kanał Sueski oraz o ataki lotnicze na irackie pola naftowe oraz rafinerię w irańskim Abadanie ${ }^{2}$. Ponadto podkreślano, że w wyniku zajęcia Bejrutu z jego zapasami ropy naftowej przeciwnik zyskałby cenną bazę morską we wschodniej części Morza Śródziemnego, co z kolei musiałoby się negatywnie odbić na brytyjskiej kontroli tej części akwenu³.

W związku z powyższym problem syryjsko-libański stał się jednym z głównych wyzwań polityki brytyjskiej po upadku Francji. Jego rozwiązanie zajęło Brytyjczykom prawie rok, kiedy to w czerwcu 1941 roku. ostatecznie zdecydowano się na opcję siłową. Zanim jednak do tego doszło, rozpatrywano wiele różnych możliwości. Istotną rolę w tych kalkulacjach odgrywała Turcja - państwo, które od początku II wojny światowej identyfikowało się z obozem aliantów, czego formalnym wyznacznikiem był podpisany 19 października 1939 roku układ o wzajemnej pomocy pomiędzy Wielką Brytanią, Francją a Turcją.

Celem niniejszego artykułu jest zanalizowanie polityki brytyjskiej wobec Turcji przez pryzmat działań Wielkiej Brytanii na rzecz rozwiązania problemu syryjsko-libańskiego. Zadanie to zmusza do postawienia szeregu pytań badawczych, takich jak: które elementy brytyjskiego ośrodka decyzyjnego dążyły do

1 The National Archives, London (dalej: NA), Cabinet Papers (dalej: CAB) 66/8/37, k. 208.

2 M. Zamir, De Gaulle and the Question of Syria and Lebanon during the Second World War: Part I, „Middle Eastern Studies” 2007, no. 5, s. 681.

${ }^{3}$ NA, CAB 66/8/37, k. 208. 
zaangażowania Turcji w kwestię syryjsko-libańską, a które były temu przeciwne? jaką rolę zwolennicy zaangażowania Turcji przypisywali temu państwu? jakie czynniki wpływały na stanowiska poszczególnych orientacji? czy z punktu widzenia interesów tureckich problem syryjsko-libański był ważny? jakie było oficjalne stanowisko rządu tureckiego? czy stanowisko to było stałe czy zmienne i na ile strona turecka była w stanie zaangażować się w militarne rozstrzygnięcie kwestii Syrii i Libanu?

Odpowiedzi na powyższe pytania umożliwiły - bezpośrednia i pośrednia metody ustalania faktów historycznych. Pierwsza z nich znalazła zastosowania przede wszystkim przy analizie działań Wielkiej Brytanii, co związane jest z faktem, że niniejszy artykuł oparty został na brytyjskich dokumentach archiwalnych. Druga odnosi się do stanowiska Turcji, które zostało zrekonstruowane na podstawie wypowiedzi decydentów tureckich w rozmowach z przedstawicielami dyplomatycznymi i wojskowymi Wielkiej Brytanii oraz na bazie wiedzy pozaźródłowej.

Tematyka niniejszego artykułu nie znalazła do tej pory odzwierciedlenia w polskiej literaturze fachowej. W dorobku światowym problematyka ta została poruszona przez Yossi Olmerta w artykule pt. Britain, Turkey and Levant Question during the Second World War. Praca ta, mimo niewątpliwego wkładu w badania nad zakreślonym wyżej problemem, ma jedną słabą stronę. Uwzględnia tylko w niewielkim stopniu rolę organów wojskowych w kształtowaniu brytyjskiej polityki wobec Syrii i Libanu oraz przemilcza fakt, że kwestia syryjsko-libańska była tematem brytyjsko-tureckich rozmów wojskowych. Tymczasem analiza ankarskich konsultacji sztabowych z początku 1941 roku pozwala nie tylko lepiej poznać politykę brytyjską, ale przede wszystkim rzuca dużo światła na stosunek strony tureckiej do problemu syryjsko-libańskiego.

1 lipca 1940 roku Londyn wydał oświadczenie, w którym stwierdzono, że rząd brytyjski nie pozwoli na okupację Syrii i Libanu przez wrogie mocarstwo ${ }^{4}$. Stanowczy ton deklaracji nie przekładał się na możliwości brytyjskie. Zdaniem CSC zajęcie terytorium Syrii i Libanu siłą w ogóle nie wchodziło w rachubę. Gdyby doszło do lądowania wojsk Osi, liczono w pierwszej kolejności na opór sił francuskich, co jednak wydawało się mało realne. Następnie miano nadzieję na aktywne wystąpienie Turcji, która mogłaby prewencyjnie zająć francuski Lewant. W ostateczności zakładano, że Wielka Brytania będzie musiała polegać na Flocie Śródziemnomorskiej, która miałaby uniemożliwić wrogi desant. W rekomendacji

${ }^{4}$ L. Woodward, British Foreign Policy in the Second World War, t. 1, London 1970, s. 561. 
dla gabinetu akcent położono na podjęcie akcji politycznej, która skutkowałaby przekonaniem Ankary do bezpośredniego zaangażowania się w wojnę. Jako kartę przetargową radzono wykorzystać obietnicę przyłączenia wysp Dodekanezu do Turcji ${ }^{5}$.

Przekonania tego nie podzielano w Foreign Office (FO), a na całą sprawę patrzono z szerszej perspektywy. Za najlepsze rozwiązanie uważano utrzymanie Syrii i Libanu pod władzą francuską, współpracę z Turcją dopuszczano jedynie w ograniczonym zakresie ${ }^{6}$. Chodziło o kontrolowanie w miarę możliwości polityki tureckiej oraz przeciwdziałanie zbrojnemu zajęciu tego obszaru, dopóki administracja francuska była w stanie nim zarządzać.

Latem 1940 roku oficjalną linią polityczną stało się stanowisko FO. War Office (WO) nie oponowało. Dobrze zdawano sobie sprawę z faktu, że rząd turecki nie przystąpi do wojny w najbliższym czasie. Poza tym po początkowej panice CSC doszedł do wniosku, że w najbliższym czasie zagrożenie dla pozycji brytyjskich od strony mandatu francuskiego zmalało do minimum. Wniosek taki wysnuto, wychodząc z założenia, że w perspektywie krótkofalowej jedynie Armia Lewantu - francuskie siły stacjonujące w Syrii i Libanie - byłaby w stanie rozpocząć działania ofensywne przeciwko oddziałom brytyjskim w Palestynie, co wydawało się nierealne ${ }^{7}$. Natomiast atak niemiecki lub włoski z terytorium syryjsko-libańskiego byłby możliwy dopiero po uprzednim przetransportowaniu drogą morską sił lądowych tych państw, co z kolei uzależniano od wycofania się floty brytyjskiej ze wschodniej części Morza Śródziemnego. CSC zalecał zatem obserwowanie rozwoju sytuacji, przy czym wytyczne te dotyczyły tylko bieżącej polityki. W perspektywie długofalowej nie zamierzano rezygnować z zamiaru współpracy z Turkami. Zakładano, że w przyszłości wojska tureckie powinny zająć północną część Syrii 8 .

Po ataku włoskim na Grecję z 28 października sztabowcy brytyjscy uznali, że państwa Osi rozpoczęły marsz w kierunku południowo-wschodnim, którego celem będzie wyparcie Brytyjczyków z Bliskiego Wschodu. Wstępem do tej zakrojonej na dużą skalę operacji wojskowej miało być podporządkowanie za pomocą środków politycznych i wojskowych rejonu bałkańskiego, wyparcie Turcji z Europy oraz zdobycie przyczółków w Anatolii, co jak sądzono, nastąpi do

\footnotetext{
5 NA, CAB 66/8/37, k. 208-211.

6 Zob. Y. Olmert, Britain, Turkey and Levant Question during the Second World War, ,,Middle Eastern Studies" 1987, no. 4, s. 438.

7 NA, CAB 66/9/36, k. 186.

8 NA, CAB 15/16, k. 240-243.
} 
końca 1940 roku. Dalsza ofensywa miała zostać podjęta na wiosnę. Zakładano, że po opanowaniu cieśnin czarnomorskich Wehrmacht ruszy w głąb Turcji w celu zdobycia Syrii oraz prawdopodobnie północnego Iraku .

W obliczu przewidywanego zagrożenia CSC doszedł do wniosku, że należy udzielić wszechstronnego wsparcia Turcji oraz zacieśnić kontrolę nad arabskim Bliskim Wschodem. W związku z powyższym uznano za stosowne podjęcie pewnych kroków wobec Syrii i Libanu - jednym z nich było opracowanie wraz ze stroną turecką planu okupacji tego obszaru ${ }^{10}$.

Rekomendacja CSC została zaakceptowana na posiedzeniu Gabinetu Wojennego w dniu 7 listopada ${ }^{11}$. Nie bez wpływu na ten fakt miało poparcie ze strony Winstona Churchilla. Brytyjski premier był przekonany, że w przeciągu najbliższych miesięcy trzeba będzie przejąć kontrolę nad Syrią i Libanem. Zdawał sobie jednak sprawę, że wojska brytyjskie do momentu pokonania Włochów w Afryce Północnej nie będą w stanie przeprowadzić takiej operacji. W związku z tym uważał, że to na Turcję powinien spaść główny ciężar kontrolowania sytuacji. Przede wszystkim chodziło mu o to, aby rząd w Ankarze wywierał stałą presję na lokalne władze, ale był również gotów zaakceptować użycie wszelkich możliwych środków, co oznaczało, że nie wykluczał samodzielnej okupacji francuskiego Lewantu przez wojska tureckie ${ }^{12}$.

Syria i Liban miały kapitalne znaczenie dla bezpieczeństwa Turcji. Ewentualne przejęcie kontroli nad nimi przez obóz Osi umożliwiłby mu atak na Turcję nie tylko z zachodu, ale również z południa. Poza tym oznaczałoby to przecięcie lądowych linii komunikacyjnych z Imperium Brytyjskim, co z kolei równałoby się wyeliminowaniu ostatniej bezpiecznej drogi, którą można było przekazywać dla Turcji pomoc wojskową.

Pierwszy wyraźny sygnał, że Turcy gotowi są na rozwiązanie siłowe pojawił się w połowie października. Turecki minister spraw zagranicznych Şükrü Saracoğlu podczas rozmowy z brytyjskim ambasadorem Hughe Knatchbullem-Hugessenem stwierdził, że w przypadku przystąpienia Turcji do wojny niezbędne będzie zapewnienie lądowego połączenia z Brytyjczykami przez Syrię, co będzie oznaczało wspólną okupację przebiegających przez ten kraj linii komunikacyjnych ${ }^{13}$. Słowa te na początku grudnia potwierdził szef tureckiego sztabu generalnego

\footnotetext{
9 NA, CAB 66/13/11, k. 70-71.

10 Ibidem, k. 73.

11 NA, CAB 65/10, k. 40-41.

12 The Churchill War Papers (dalej: CWP), oprac. M. Gilbert, t. II, London 1994, s. 1084-1085.

13 NA, CAB 21/1182, k. 40.
} 
marszałek Fevzi Çakmak w rozmowie z admirałem Howardem Kellym. Brytyjczyk odniósł nawet wrażenie, że w przypadku zwłoki ze strony Londynu Turcy zdecydują się samotnie wkroczyć do Syrii i Libanu ${ }^{14}$.

Sygnały te napawały nadzieją. Okazją do ich sprawdzenia były zaplanowane na styczeń brytyjsko-tureckie konsultacje sztabowe. W ich programie jeden z punktów, który został zaproponowany zresztą przez obie strony, dotyczył Syrii i Libanu ${ }^{15}$.

Temat ten omawiany był pierwszego dnia posiedzeń, czyli 15 stycznia 1941 roku. Reprezentujący stronę turecką gen. Asim Gündüz, zastępca szefa sztabu generalnego, na wstępie zwrócił uwagę, że rozejm, który Francja zawarła z państwami Osi, doprowadził do odcięcia lądowych szlaków między Turcją a Bliskim Wschodem. Jego zdaniem powagi sytuacji dodawał fakt, że Włosi mogli uzbroić w sprzęt z magazynów Armii Lewantu Ormian, Kurdów, Asyryjczyków oraz Arabów, którzy niechętnie byli nastawieni wobec Turków, a w przypadku tych ostatnich również wobec Brytyjczyków. Poza tym za realne uważał przerzucenie oddziałów włoskich do Syrii i Libanu, co mogło zagrozić od północy Kanałowi Sueskiemu. Następnie stwierdził, że zażegnanie tych zagrożeń przerośnie stronę brytyjską i dlatego powinna w tej materii podjąć współpracę z Turcją. Według niego w grę wchodziły dwie możliwości: nacisk dyplomatyczny albo okupacja. Ta druga opcja miała zostać wprowadzona w życie, gdyby zawiodły pierwsza. Poza tym podkreślał potrzebę przeprowadzenia zawczasu przygotowań, aby w razie przystąpienia Turcji do wojny móc bezzwłocznie przeprowadzić operacje zajęcia Syrii i Libanu ${ }^{16}$.

Brytyjczycy nie zgodzili się z wywodami Gündüza. Stojący na czele delegacji gen. James Marshall-Cornwall ocenił postawę swojego interlokutora za zbyt pesymistyczną ${ }^{17}$. Jednak turecki generał upierał się przy swoim zdaniu, a następnie przedstawił turecki plan okupacji Syrii i Libanu. Turcy zamierzali użyć trzech i pół dywizji piechoty oraz jednej dywizji kawalerii. Oddziały te były już rozmieszczane w południowej Anatolii. W pierwszej kolejności zakładano zajęcie rejonu Aleppo. Następnie gros sił miało posuwać się na miejscowość Rajak, ubezpieczane od zachodu przez oddziały maszerujące wzdłuż wybrzeża. Wojska tureckie miały zatrzymać się po dotarciu do linii demarkacyjnej, która miała

14 NA, FO 371/25018, k. 122.

15 NA, FO 371/25022, k. 298-299, NA, FO 371/30028, s. 1-2.

16 WO 106/3118, s. 3-6.

17 Ibidem, s. 7-12. 
zaczynać się na południe od miejscowości Baalbek, i skręcając po delikatnym łuku w kierunku północnym, miała dochodzić do granicy z Irakiem. Tym samym Turcy planowali zająć około dwóch trzecich terytorium syryjsko-libańskiego, obejmującego takie miasta, jak: Aleppo, Homs i Trypolis. Region południowy z Damaszkiem i Bejrutem miał znaleźć się pod okupacją brytyjską. Taki podział stref okupacyjnych uzasadniano tym, że na południe od proponowanej linii przeważała ludność arabska, a na północy znajdował się duży odsetek ludności pochodzenia tureckiego ${ }^{18}$.

Strona brytyjska nie przedstawiła żadnych własnych propozycji. Marshall-Cornwall stwierdził, że Brytyjczycy nie przygotowali jeszcze żadnych konkretnych planów. Ponadto dodał, że Wielka Brytania głównie nadzieje wiąże z działaniami „Wolnej Francji”. Podkreślił również, że okupacja wojskowa doprowadzi do związania na terenie Syrii i Libanu trzech dywizji tureckich i dwóch brytyjskich, które mogłyby zostać wykorzystane na innych obszarach operacyjnych ${ }^{19}$. Mimo tych zastrzeżeń strona turecka dopięła swego. W podsumowaniu rozmów ankarskich zapisano, że gdy Turcja przystąpi do wojny, wobec Syrii i Libanu podjęte zostaną zdecydowane działania. W pierwszej kolejności Ankara i Londyn miały zwrócić się do władz w Vichy z żądaniem niezwłocznego przekazania pod kontrolę brytyjsko-turecką infrastruktury komunikacyjnej. W przypadku odmowy wojska Wielkiej Brytanii i Turcji miały zająć terytorium syryjsko-libańskie. W takiej sytuacji Brytyjczycy zobowiązywali się do udzielenia Turkom pomocy lotniczej i morskiej. Linię rozgraniczającą strefy okupacyjne ustalono zgodnie z turecką propozycją ${ }^{20}$.

Rozmowy ankarskie potwierdziły gotowość Turcji do rozwiązania kwestii syryjsko-libańskiej za pomocą siły. Brytyjczycy z pewnością byli zaskoczeni stanowczą postawą strony tureckiej. Doświadczenia nabyte w dotychczasowych konsultacjach sztabowych wskazywały bowiem, że Turcy bardzo rzadko i niechętnie zdradzali swoje plany, domagając się najpierw określenia zakresu pomocy, jaką alianci byli gotowi im udzielić. Tym razem było odwrotnie. To przede wszystkim sztabowcy tureccy dążyli do wymiany informacji dotyczących zamierzeń militarnych względem Syrii i Libanu. Na dalszy plan zeszła również kwestia ewentualnego wsparcia ze strony Wielkiej Brytanii.

18 Ibidem, s. 29-30.

19 Ibidem, s. 30-31.

20 Przebiegała następująco: Byblos-Heliopolis-Nebek-Bir Bassiri-Bira Sakar-Bir Ourka-Abu Kemal, WO 201/1074, 20A, s. 1-2. 
Wydaje się, że głównym motywem, którym kierowała się strona turecka, była chęć zabezpieczenia połączeń lądowych z Zatoką Perską oraz Palestyną. Ich znaczenie podkreślał nie tylko Gündüz w trakcie rozmów ankarskich, ale również turecki prezydent Ismet Inönü podczas lutowej wizyty w Turcji szefa FO Anthony'ego Edena ${ }^{21}$. Pewne znaczenie miał również zamiar przejęcia francuskich zapasów wojskowych. Dla armii tureckiej chronicznie zmagającej się $\mathrm{z}$ brakami w wyposażeniu, których nie była w stanie zaspokoić Wielka Brytania, magazyny zdemobilizowanej Armii Lewantu stanowiły łakomy kąsek. Hipotezę tę potwierdzają słowa Gündüza, który stwierdził, że najprostszym sposobem pozyskania ciężarówek z francuskich magazynów byłaby okupacja Syrii i Libanu ${ }^{22}$.

Zadziwiające natomiast było stanowisko strony brytyjskiej, które można określić jako co najmniej powściągliwe. Znalazło ono zresztą odzwierciedlenie w dokumencie podsumowującym, w którym była mowa, że z brytyjskiego punktu widzenia minusy wynikające z podjęcia działań zbrojnych przeciwko Syrii i Libanowi nie zrównoważą korzyści płynących z zabezpieczenia szlaków komunikacyjnych przebiegających przez te terytoria ${ }^{23}$. Wynikało ono $\mathrm{z}$ instrukcji WO, zgodnie z którymi delegacja brytyjska nie była upoważniona, po pierwsze, do ustalenia warunków, w jakich okupacja Syrii i Libanu okazałaby się konieczna, a po drugie, do podejmowania dyskusji na temat przyszłego statusu politycznego tych terenów. Ponadto nie mogła wyrazić zgody na samodzielną akcję militarną Turcji ${ }^{24}$. Instrukcje te były wyrazem przewagi, jaką ponownie uzyskali zwolennicy rozwiązania kwestii syryjsko-libańskiej na drodze dyplomatycznej. Wspominał o tym Marshall-Cornwall w trakcie rozmów z Turkami, stwierdzając, że obecnie "polityka brytyjska dąży do odciągnięcia Syrii od Francji Vichy” ${ }^{25}$. Zmiana ta wynikała w głównej mierze z dwóch względów. Z jednej strony nie sprawdziły się przewidywania CSC. Ofensywa państw Osi na Bałkanach mogła ruszyć dopiero na wiosnę 1941 roku, dzięki czemu zyskiwano czas, co z kolei umożliwiało podjęcie akcji politycznej. Z drugiej strony uwaga Brytyjczyków skupiała się w tym czasie głównie na określeniu nowej strategii we wschodniej części Morza Śródziemnego. Zwycięstwa wojsk brytyjskich nad armią włoską w Afryce Północnej wywołały dyskusję na temat wykorzystania rezerwy operacyjnej

\footnotetext{
21 Y. Olmert, op. cit., s. 442.

22 WO 106/3118, s. 109.

${ }^{23}$ WO 201/1074, 20A, s. 1-2.

${ }^{24}$ WO 106/3129, 35A.

25 WO 106/3118, s. 28.
} 
tworzonej w Egipcie. W tym względzie wykrystalizowały się dwa stronnictwa, z których jedno dążyło do kontynuowania ofensywy w Libii, aż do wyrzucenia Włochów z Afryki Północnej, podczas gdy drugie chciało wykorzystać koncentrujące się wojska do interwencji na Bałkanach. Syria i Liban w tych kalkulacjach schodziły na dalszy plan. Siłowemu rozwiązaniu nie sprzyjało również negatywne stanowisko głównodowodzącego armią brytyjską na Bliskim Wschodzie gen. Archibalda Wavella ${ }^{26}$.

Wiosną 1941 roku III Rzesza przystąpiła do zmasowanej ofensywy we wschodniej części Morza Śródziemnego. W kwietniu zajęto Grecję i Jugosławię, a wojska włosko-niemieckie odzyskały utracone tereny w Afryce Północnej. Sukcesy te wywołały w Londynie obawy, że kolejnym celem Niemców w pochodzie na Bliski Wschód może być Syria i Liban. Stawało się to tym bardziej prawdopodobne, gdyż z obszaru tego można było udzielić bezpośredniej pomocy antybrytyjskiemu powstaniu w Iraku, które wybuchło z początkiem maja ${ }^{27}$. Poza tym wywiad zaczął przekazywać informacje o wojskowej penetracji Syrii i Libanu przez stronę niemiecką ${ }^{28}$.

Sytuacja była na tyle poważna, że 14 maja, podczas zebrania Komitetu Obrony (DC), Churchill uznał za niezbędne stworzenie korpusu interwencyjnego ${ }^{29}$. Pięć dni później decyzja ta zyskała uznanie Gabinetu Wojennego, który nakazał Wavellowi przygotować odpowiednie siły do okupacji Syrii i Libanu ${ }^{30}$. Pod koniec maja głównodowodzący na Bliskim W schodzie przedstawił plan operacji, która otrzymała kryptonim „Exporter” ${ }^{31}$.

Decyzja o podjęciu przygotowań do operacji wojskowej wywołała dyskusję na temat zaangażowania tureckiego. Propozycja aktywnego włączenia Turcji do działań wyszła od Edena. 15 maja szef FO poinformował, że zwrócono się do Ankary z prośbą o zmobilizowanie jej wojsk na granicy z Irakiem i Syrią. Jego zdaniem miał być to test, który pozwoliłby zorientować się w stanowisku tureckim. Gdyby odpowiedź była pozytywna, to wówczas można było spróbować wywrzeć nacisk na Turcję, aby zajęła rejon Aleppo ${ }^{32}$. Opinia Edena nie odzwierciedlała poglądów jego podwładnych. W FO zwrócono uwagę, że wkroczenie

${ }^{26}$ Y. Olmert, op.cit., s. 442.

27 Zob. Ł. Hirszowicz, III Rzesza i arabski wschód, Warszawa 1963, s. 188-243.

28 F.H. Hinsley, British Intelligence in the Second World War, t. 1, London 1979, s. 413.

${ }^{29}$ CWP, III, s. 666.

${ }^{30}$ NA, CAB 65/22/19, k. 146-147.

${ }^{31}$ I.S.O. Playfair, The Mediterranean and Middle East, t. 2, London 1956, s. 203.

32 Y. Olmert, op.cit., s. 444. 
Turków do północnej Syrii doprowadzi do zjednoczenia Francuzów i Arabów przeciwko napaści oraz prawdopodobnie uniemożliwi współpracę z „Wolną Francją" ${ }^{3}$. Sceptycznie do tego pomysłu podchodził również Połączony Sztab Planowania (JPC), którego zdaniem udział Turcji miał być wątpliwy, gdyż nie będzie chciała prowokować III Rzeszy ${ }^{34}$.

Co prawda Eden zgadzał się z poglądami swoich podwładnych oraz opinią JPC, ale był przekonany, że nad tymi zastrzeżeniami musi wziąć górę niedopuszczenie do zajęcia francuskiego Lewantu przez III Rzeszę oraz zabezpieczenie połączeń z Turcją. Dlatego też podtrzymał swoje dotychczasowe stanowisko co do udziału Turków w okupacji Syrii i Libanu. Miał nadzieję, że tureckie interesy w północnej Syrii sprawią, że Ankara zaangażuje się bezpośrednio. Jego zdaniem szansę na to mogło zwiększyć szybkie zajęcie przez wojska brytyjskie Bagdadu, co stanowiłoby przełom w zdławieniu powstania w Iraku ${ }^{35}$.

Podobne stanowisko zajmował Churchill, przy czym w jego kalkulacjach równorzędną rolę odgrywały przesłanki zarówno strategiczne, jak i polityczne. $\mathrm{Za}$ istotne uważał uzyskanie poparcia arabskiego. Jego zdaniem można było je zdobyć w wyniku proklamowania niepodległości Syrii. Powstałe państwo zamierzał związać trwałymi sojuszami z Wielką Brytanią i Turcją. Z jednej strony oznaczałoby to osiągnięcie jednego z głównych celów interwencji, czyli ustanowienie bezpiecznego połączenia między posiadłościami brytyjskimi a terytorium tureckim. Z drugiej natomiast umocniłoby więzy polityczne z Ankarą, na co dodatkowo korzystnie miało wpłynąć ewentualne przekazanie stronie tureckiej północnej części Syrii ${ }^{36}$.

Do zaangażowania Turcji w operację „Exporter” dążył również Wavell. Kierował się on motywami stricte wojskowymi. Do ataku na Syrię i Liban mógł użyć tylko sił z Palestyny, które były niewielkie. Tymczasem w swoim planie podkreślał, że do okupacji całego terytorium Syrii i Libanu potrzebowałby dwóch dywizji piechoty oraz brygady pancernej. Zastrzegał więc, że wojska brytyjskie nawet wspierane przez oddziały „Wolnej Francji” będą w stanie dotrzeć najdalej do Bejrutu, Rajaku i Damaszku oraz ewentualnie dokonać rajdów na Homs oraz Trypolis. W tej sytuacji za niezbędny uważał udział w operacji sił tureckich, które przede wszystkim miały zająć rejon Aleppo, co uniemożliwiłoby przeciwnikowi

\footnotetext{
33 Ibidem.

34 Ibidem.

35 NA, CAB 66/16/39, k. 28.

36 CWP, III, s. 687.
} 
stworzenie bazy wypadowej w północnej Syrii oraz skutecznie przeciwdziałałoby niemieckiemu desantowi ${ }^{37}$.

Wszystkie te argumenty przeważyły szalę na rzecz włączenia Turcji do działań przeciwko Syrii i Libanowi. 27 maja, podczas spotkania DC, udzielono zielonego światła dla operacji „Eksporter” oraz zdecydowano zaproponować rządowi tureckiemu objęcie okupacją rejonu Aleppo ${ }^{38}$. Nazajutrz decyzja ta została przekazana Knatchbullowi-Hugessenowi ${ }^{39}$.

Czy Wielka Brytania mogła liczyć na poparcie tureckie? Wiosną 1941 roku wiele czynników działało na niekorzyść Londynu. Klęski Brytyjczyków na Bałkanach i w Afryce Północnej nie pozostały bez szkody dla ich prestiżu. Wojna przybliżyła się do granic tureckich, a zagrożenie ze strony ataku obozu Osi wzrosło. Nastroje w Turcji były minorowe ${ }^{40}$. Turcja co prawda zobowiązała się podczas rozmów styczniowych do wzięcia udziału w okupacji Syrii i Libanu, ale uczynić to miała dopiero, gdyby znalazła się w stanie wojny. Tymczasem wydawało się, że coraz bardziej dąży do neutralności. Między innymi świadczyło o tym stanowisko tureckie wobec powstania w Iraku. Ankara, zamiast poprzeć w tym konflikcie Londyn, zaoferowała swoją mediację, tym samym uznając de facto nielegalny rząd Raszida Aliego al-Kajlaniego ${ }^{41}$.

Nadal jednak były oznaki, że Turcy mogą aktywnie zaangażować się w rozwiązanie kwestii syryjsko-libańskiej - od połowy maja rząd turecki rozpoczął koncentrować swoje wojska na granicy syryjskiej oraz poprosił Brytyjczyków o udostępnienie planów dotyczących okupacji Syrii i Libanu ${ }^{42}$. Poza tym przywódcy Turcji sprawiali wrażenie nieugiętych oraz niezłamanych sukcesami państw Osi. Takie sygnały docierały do Knatchbulla-Hugessena zarówno od prezydenta Inönü, jak i od marszałka Çakmaka ${ }^{43}$.

W tych okolicznościach 2 czerwca 1941 roku Knatchbull-Hugessen przekazał Saracoğlu propozycję współudziału Turcji w operacji „Eksporter” poprzez objęcie okupacją rejonu Aleppo. Turecki minister spraw zagranicznych nie udzielił natychmiastowej odpowiedzi. Jednak z przebiegu rozmowy można była wywnioskować, że nastawienie Saracoğlu było pozytywne. Zrobił on bowiem aluzję do

\footnotetext{
37 Y. Olmert, op.cit., s. 444 i 445, I.S.O. Playfair, op.cit., s. 203.

38 CWP, III, s. 724-25.

39 NA, CAB 65/18/34, k. 156.

40 NA, FO 371/30076, k. 107.

41 Ł. Hirszowicz, op.cit., s. 218-221.

42 NA, CAB 65/22/19, k. 146.

43 NA, FO 371/30076, k. 107.
} 
niesprawiedliwości z przeszłości, które obecnie Turcja chciałaby naprawić. Poza tym stwierdził, że nie jest specjalnie zaniepokojony możliwością naruszenia interesów niemieckich ${ }^{44}$. Było to jednak tylko wrażenie, gdyż ostatecznie Turcy odrzucili propozycję brytyjską, tłumacząc ją obawą przed wojną z Francją Vichy lub III Rzeszą. Zapewniono jednak, że koncentracja wojsk tureckich na granicy z Syrią zostanie utrzymana ${ }^{45}$.

Wówczas Brytyjczycy zdecydowali się przeprowadzić operację „Exporter” jedynie przy udziale „Wolnej Francji”. Atak rozpoczęto 8 czerwca 1941 roku. Mimo początkowych sukcesów szybko okazało się, że gen. Wavell miał rację, twierdząc, że nie będzie w stanie opanować całej Syrii i Libanu. Wobec słabości własnych sił i tężejącego oporu wojsk Vichy tempo ofensywy znacznie spadło. Dopiero wzmocnienie jednostkami, które stłumiły powstanie w Iraku, umożliwiło złamanie oporu przeciwnika. Operacja zakończyła się sukcesem 14 lipca $1941 \mathrm{roku}^{46}$.

Pomimo że Turcy nie zdecydowali się wziąć udziału w operacji „Exporter”, to sprzyjali stronie brytyjskiej. Zapewnienia Saracoğlu, że wojska tureckie nadal będą się koncentrowały nad granicą syryjską, nie okazały się gołosłowne. Faktycznie przez cały okres trwania walk we francuskim Lewancie Turcy utrzymywali w gotowości bojowej na granicy z Syrią XVII Korpus Armijny ${ }^{47}$. Poza tym Ankara nie uległa naciskom ze strony Vichy, popieranej w tej kwestii przez III Rzeszę, i nie przepuściła przez swoje terytorium uzupełnień dla Armii Lewantu ${ }^{48}$.

Równocześnie jednak rząd turecki prowadził własną grę. Na początku lipca, podczas rozmów ze specjalnym wysłannikiem marszałka Pétaina Jakiem Benoist-Mechinem, Saracoğlu zaproponował, że w przypadku załamania się oporu wojsk francuskich rząd Vichy powinien zwrócić się do Ankary z propozycją zajęcia Syrii przez armię turecką. W zamian Turcy zagwarantowaliby powrót żołnierzy francuskich do domu oraz zwrot Francji okupowanych terytoriów po zakończeniu wojny, z wyjątkiem terenów, przez które przebiegała kolej bagdadzka. Francuzi nie przyjęli jednak tej propozycji ${ }^{49}$. Mimo to strona turecka nie

\footnotetext{
${ }^{44}$ L. Woodward, op.cit., s. 566.

45 Y. Olmert, op.cit., s. 447; L. Woodward, op.cit., s. 566.

46 Zob. C. Buckley, Five Ventures: Iraq, Syria, Persia, Madagascar, Dodecanese, London 1977, s. $56-138$.

47 NA, WO 33/1690, s. 25.

48 Documents on German Foreign Policy 1918-1945 (dalej: DGFP), Series D, Vol. XII, London 1962, s. 1056.

49 DGFP, D, XIII, s. 82-83.
} 
rezygnowała. Kilka dni później turecki minister spraw zagranicznych zwrócił się do ambasadora niemieckiego Franza von Papena z prośbą o udzielenie przez Berlin zezwolenia na tymczasowe zajęcie przez wojska tureckie terenów Syrii, aż do linii Abu-Kemal - Tripoli. Argumentowano to tym, że większa część francuskiego Lewantu nie wpadłaby w ręce aliantów, a żołnierze wierni Vichy mogliby zostać repatriowani do Francji kontynentalnej ${ }^{50}$. Znamienne, że w rozmowach z Niemcami Saracoğlu wspominał o tej samej linii, która w styczniu 1941 roku została ustalona jako granica stref okupacyjnych w przypadku wspólnej interwencji brytyjsko-tureckiej. Gdyby Berlin zgodził się na propozycję Ankary, to Turcy mogliby poinformować Brytyjczyków, że decydują się na wsparcie działań aliantów i następnie bez ryzyka zająć interesujący ich obszar. Tym samym nie dość, że osiągnęliby cel, jakim było uzyskanie kontroli nad syryjskim odcinkiem kolei bagdadzkiej, to jeszcze z jednej strony nie pogorszyliby swoich stosunków z III Rzeszą, a z drugiej pokazaliby, że nadal lojalnie stoją za Wielką Brytanią. Realizacja tego wymarzonego dla strony tureckiej scenariusza okazała się jednak niemożliwa ze względu na sprzeciw Niemiec ${ }^{51}$.

Reasumując, od samego początku Brytyjczycy mieli problem z wypracowaniem jednolitej linii postępowania wobec Syrii i Libanu. Ograniczone możliwości wojskowe, komplikacje natury politycznej, rozwój sytuacji militarnej we wschodniej części Morza Śródziemnego oraz ścieranie się zwolenników miękkiego i twardego kursu sprawiły, że pojawiło się kilka koncepcji, które w zależności od warunków w różnym stopniu wpływały na politykę brytyjską.

Jednym z nich było rozwiązanie problemu syryjsko-libańskiego w oparciu o interwencje zbrojną Turcji. Pomysł ten narodził się w gronie sztabowców brytyjskich i z tego też względu cieszył się w pierwszej kolejności poparciem kół wojskowych. W przeciwieństwie bowiem do cywilnych przedstawicieli establishmentu wyżsi oficerowie kierowali się przede wszystkim przesłankami natury militarnej i bagatelizowali przewidywane komplikacje polityczne. Nie oznacza to jednak, że nie znali realiów politycznych. CSC zdawał sobie sprawę z faktu, że Turcy mogą nie wziąć na swoje barki ciężaru akcji militarnej we francuskim Lewancie, gdyż nie będą chcieli prowokować Niemców. Mimo to uważał, że w perspektywie długofalowej należy działać na rzecz urzeczywistnienia tureckiej interwencji. Przeciwne stanowisko zajmowało FO, które ze względu na politykę bliskowschodnią z jednej strony sądziło, że bezpośrednie tureckie zaangażowanie

\footnotetext{
50 Ibidem, s. 106.

51 Ibidem, s. 123.
} 
na polu militarnym negatywnie odbije się na wizerunku Wielkiej Brytanii wśród ludności arabskiej, a $\mathrm{z}$ drugiej obawiało się w razie załamania się administracji francuskiej w Syrii i Libanie powstania arabskiego Piemontu, co zagroziłoby brytyjskim wpływom.

Ten punkt widzenia nie odpowiadał z kolei brytyjskiemu premierowi, który był zwolennikiem twardego kursu wobec francuskiego Lewantu. Świadom słabej pozycji „Wolnej Francji” sądził, że to Turcja powinna wziąć na siebie ciężar kontrolowania sytuacji w tym rejonie i prawdopodobnie gotów był przystać nawet na samodzielną akcję wojsk tureckich. Poza tym bagatelizował zastrzeżenia FO. Z jednej strony uważał, że prestiż brytyjski nie ucierpi, jeżeli Londyn wyda deklarację, w wyniku której zostanie proklamowana niepodległość Syrii, a $\mathrm{z}$ drugiej, że upadek administracji francuskiej nie będzie miał negatywnych skutków politycznych, jeżeli Wielka Brytania i Turcja roztoczą protekcję nad nowo powstałym państwem. Dodatkową zaletą takiego stanu rzeczy byłoby zacieśnienie, poluzowanych w wyniku brytyjskich porażek z wiosny 1941 roku, więzów z Ankarą.

Ważnym sprzymierzeńcem Churchilla w tym względzie był szef FO Anthony Eden. Mimo że zgadzał się on z opinią swoich podwładnych, to jednak za priorytet uważał wyeliminowanie wpływów państw Osi z Syrii i Libanu, a według niego możliwe to było jedynie przy aktywnym udziale strony tureckiej.

Nie ulega wątpliwości, że strona turecka chciała objąć okupacją północną i środkową Syrię. Świadczyły o tym nie tylko aluzje czynione przez Inönü czy Saracoğlu, ale przede wszystkim przebieg i ustalenia konsultacji sztabowych ze stycznia 1941 roku czy też działania dyplomatyczne z przełomu czerwca i lipca.

Dążenie to było uwarunkowane licznymi przyczynami. Poza już wymienionymi w tekście warto zwrócić uwagę na jeszcze jedną. Stanowisko tureckie mogło wynikać również z przesłanek rewizjonistycznych. Nie byłby to pierwszy przypadek pretensji terytorialnych względem francuskiego Lewantu. W latach trzydziestych Turcja wysuwała żądania wobec sandżaku Aleksandretty. Działania Ankary okazały się na tyle skuteczne, że w czerwcu 1939 roku obszar ten został przyłączony do Turcji jako vilayet Hatay ${ }^{52}$. Co prawda wówczas nie przedstawiano innych żądań, ale mogło to po prostu świadczyć o przyjęciu taktyki małych kroków. Należy bowiem pamiętać, że zgodnie z Paktem Narodowym (Misakı Millı) z 1920 roku, który m.in. określał zakres rewindykacji terytorialnych

52 Zob. Y. Güçlü, The Question of the Sanjak of Alexandretta. A Study in Turkish-French-Syrian Relations, Ankara 2001, s. 368. 
ruchu kemalistowskiego, północna Syria znaleźć się miała w granicach państwa tureckiego ${ }^{53}$. Powyższe założenie należy traktować jednak jako hipotezę, której falsyfikacja, ze względu na ograniczenia wynikające z bazy źródłowej, nie może zostać przeprowadzona $\mathrm{w}$ niniejszym artykule.

Przejęcie kontroli nad północną i środkową Syrią nie stanowiło jednak priorytetu w polityce tureckiej. Istniały granice, których Ankara nie była gotowa przekroczyć. Zwyciężył zdrowy rozsądek, który podpowiadał, że od nabytków terytorialnych ważniejsze jest uniknięcie wojny. Z tego też względu strona turecka ostatecznie odrzuciła brytyjską propozycję wzięcia udziału w operacji „Exporter”.

53 Zob. J. Felton, The Contemporary Middle East. A Documentary History, Washington 2008, s. $634-635$. 